\title{
Jurisprudence of Love in Paul's Letter to the Romans
}

\author{
Joshua Neoh
}

\begin{abstract}
Paul proclaims that Christ is the end of law. The new Christian community promises to be a community sustained not by law, but by love. His zeal for love reinforces his proclamation of Christ as the end of law, for love is lawless, literally outside of law. In contrast to Moses who establishes the rule of law on Mount Sinai, Paul proclaims the power of love over law and asserts the inherent lawlessness of love. Legal rules predict human behaviour; but love makes human actions unpredictable. Legal rules dictate outcomes; but love is, by definition, free. However, inasmuch as love is free, love is also fleeting. According to Paul, Christianity marks the end of law and the dawn of love, but it does not take long for the first church council to be formed and decrees to be issued. The promise of a lawless community ends up with codes of canon law. The modern political state carries with it this ancient theological baggage. We inherit from Paul a particular cognitive dissonance: we dream in the language of love, but speak in the language of law. The radical ideal of love as the ultimate negation of law remains a powerful eschatological vision in our theo-political imaginary.
\end{abstract}

\section{Introduction: A Critique of Nomolatry}

We live under the rule of law, and we take great pride in that fact. No event, actor or claim escapes the rule of law - there is no field of life in which law has not or cannot enter. ${ }^{1}$ Many law journal articles today follow a predictable paradigm: an article typically begins with the identification of a social or political problem. The problem is then traced to a lack of regulation in that area. The article then ends with a proposed solution, which produces more law, and which in turn results in the juridification of more relationships. This phenomenon is even more pronounced in the field of international human rights. With the proliferation of noticeable human rights violations, we see a proliferation of human rights declarations and monitoring bodies. Charles Taylor calls this obsession with law 'rule fetishism' or 'nomolatry'. ${ }^{2}$ When a relationship is juridified, or when we recast a relationship in legal terms, that relationship becomes a mediated relationship: the relationship becomes mediated by law.

The language of law speaks in terms of norms, whether in the form of rules or commands. Hart defines law as a system of rules. Austin defines

$1 \quad$ Paul Kahn, Law and Love: The Trials of King Lear (Yale University Press, 2000) xvi.

2 Charles Taylor, 'Perils of Moralism' in Dilemmas and Connections: Selected Essays (Harvard University Press, 2011) 347-366. 
law as the command of a sovereign. Law prescribes and proscribes, categorically, what one can and cannot do. Waldron calls this normative aspect of law the 'deontic character' of law: law guides action 'by requiring that certain things be done rather than just commending them to us' and 'by prohibiting certain things rather than merely explaining why they may not be a good idea'. ${ }^{3}$ Laws command and demand obedience. If you are a legal positivist, like Hart and Austin, you will think that the demands of law are social facts. If you are a natural lawyer, you will think that the demands of law are moral facts. Natural law, insofar as it is couched in terms of prescription and proscription, is still speaking within the language of law: in order for natural law to be law, it has to be 'capable of ordering our actions and interactions'. ${ }^{4}$ If you are an optimist, you will think of law as a form of rationality. If you are a pessimist, you will think of law as a form of violence. All these different conceptions of law, whether positivistic or naturalistic, whether rational or violent, share a common understanding of law as being characterised by hierarchy and heteronomy. The authoritative nature of law demands that one submits the individual will to the extraneous will of the law. ${ }^{5}$ Law creates 'a certain kind of social relations - authority relations'. ${ }^{6}$

To be clear, I am not drawing the clichéd distinction between positive law and morality. Rule fetishism or nomolatry can apply to both positive law and morality, for both positive law and morality can be rule-bound. 'Some ethical systems have features that are formidably law-like: they posit a set of uncompromising demands, they are imbued with a general spirit of obligation, they are devoted to the minute disciplining of certain aspects of behavior, and they exhibit intricate systems of rights and duties.' 7 These ethical systems assume that 'morality can be defined in terms of a code of obligatory and forbidden actions', and they can range from rule utilitarianism to Kantian universalisable maxims. ${ }^{8}$ Kant, for example, presents some of morality's most important norms as categorical imperatives, which operate with a law-like logic. ${ }^{9}$ These moral theories identify morality with a universal code, generated from a single philosophical idea. The same applies to moral systems based on religious beliefs: religious dogma often identifies morality with a universal code, generated from a single religious source - that religious source is often a code in the literal sense of the word. Many religious groups claim to possess a text, or a series of texts, which tell them exactly how they should live their lives.

$3 \quad$ Jeremy Waldron, 'What is Natural Law Like?' (Working Paper No 12-27, Public Law \& Legal Theory Research Paper Series, New York University School of Law, 2012) 4-5.

4 Ibid, 1.

$5 \quad$ Neil MacCormick, Institutions of Law (Oxford University Press, 2007) 251.

6 Leslie Green, The Authority of the State (Clarendon Press, 1988) 19-20.

7 Jeremy Waldron, 'Dead to the Law: Paul's Antinomianism' (2006) 28 Cardozo Law Review 301, 306.

8 Charles Taylor, A Secular Age (Harvard University Press, 2007) 705.

9 Waldron, above n 3, 13; Immanuel Kant, Groundwork of the Metaphysics of Morals (Mary Gregor trans, Cambridge University Press, 1991) 24ff. 
When a moral system, whether religious or secular, is conceived of as a set of law-like precepts, setting out rights and obligations, that moral system has already been subsumed within the framework of juridical thought: within this nomocratic world view, moral relationships are conceptualised in legal terms. ${ }^{10}$

This paper is a critique of this impulse to order the world according to the paradigm of law. It examines the "closure of the legal mind in the belief in a norm or rule which speaks as "the law". ${ }^{11}$ I want to invite us to consider what a lawful and law-filled life entails. By choosing to live under the rule of law, what have we given up? What demands does the law make upon our affective lives? Even if we can't escape the rule of law, and even if we require it as a matter of necessity, it is important for us to realise that the rule of law is not an unequivocal good. Or in the words of Taylor, 'codes, even the best codes, can become idolatrous traps' ${ }^{12}$ To go about our daily business, we may well require juridical institutions, but we must never assume that these institutions are a full expression of our most basic moral and existential concerns - as weighty as questions of rights are, they must ultimately be subordinated to the fundamental question of 'how we are to lead lives of value and significance'. ${ }^{13}$

\section{JuRisprudence of Paul as Jurisprudence of Love}

As a way to mount a critique of law, I want to contrast the concept of law with the ideal of love. For a sharp view of that contrast, we will have to (re)turn to Paul's Letter to the Romans. My central thesis is that the jurisprudence of Paul is a jurisprudence of love. It presents to us with a deep tension between the idea of law and the ideal of love. More specifically, it presents love as a fundamental critique of law.

A number of contemporary philosophers have embarked on various projects to reclaim Paul for a secular audience. For example, Agamben wants to 'restore Paul's letters to the status of the fundamental messianic text for the Western tradition', ${ }^{14}$ and Badiou presents Paul as the foundation of universalism in the West. ${ }^{15}$ My contribution, in this paper and the larger project beyond this paper, is to reconstruct Paul's jurisprudence as a jurisprudence of love, which is Paul's most enduring and endearing contribution to Western jurisprudence. This paper is situated within two trends in contemporary scholarship. First, it taps into the current secular philosophical revival of interest in Paul, as reflected in the writings of Agamben

10 Nigel Simmonds, 'Judgment and Mercy' (1993) 13 Oxford Journal of Legal Studies 52, 65, 68.

11 Peter Goodrich, Law in the Courts of Love (Routledge, 1996) vii.

12 Taylor, above n 8, 743.

13 Simmonds, above n 10, 68.

14 Giorgio Agamben, The Time that Remains: A Commentary on the Letter to the Romans (Patricia Dailey trans, Stanford University Press, 2005) 1.

15 Alan Badiou, Saint Paul: The Foundation of Universalism (Ray Brassier trans, Stanford University Press, 2003). 
and Badiou. However, unlike Agamben and Badiou, my primary concern is neither messianism nor universalism. My concern is far less grandiose. The central concern of this paper is the analytic structure of the concept of law, as compared to love. Second, it joins those who adopt a critical evaluative attitude towards the increasing juridification of social relations, or what scholars like Taylor calls the phenomenon of rule fetishism and nomolatry. ${ }^{16}$ It mounts a critique of law from the vantage point of love.

Paul's view of the law could be described, charitably, as unsystematic, and less charitably, as contradictory and incoherent. He moves from singing praises about the law to screaming condemnation about it. I want to argue that his contradictory stance about the law is traceable to a deeper tension between the idea of law and the ideal of love, a tension that we still live with today, almost two millennia since Paul wrote the Letter to the Romans. Like Paul, we are committed to both law and love, and we find ourselves trapped between the two.

I will make some methodological remarks before proceeding to the substance of the analysis. There will be a tripartite structure to my substantive analysis. First, I will present Paul's critique of the idea of law. Second, I will present Paul's portrayal of love as the counter-ideal to law. Third, I will try to show that, notwithstanding his heated condemnation and denunciation of law, Paul could not free himself from grips of the legal imagination. Hence, Paul's political theology could properly be classified as jurisprudence. In conclusion, I will examine how Paul's jurisprudence of love fits into contemporary legal discourse.

\section{Methodology}

There is an established field of New Testament scholarship called 'Paul and the Law'. I have consciously named my project 'the jurisprudence of Paul' to signal a desire on my part to move Paul from the domain of biblical studies to the domain of contemporary legal theory. I want to make Paul 'an interlocutor of our time'. ${ }^{17} \mathrm{I}$ hope to present a reading of Paul that extracts from his letters certain key jurisprudential insights, which speak to our contemporary predicament. What I am doing is not historical criticism of the sort that is in vogue in certain strands of biblical scholarship; ${ }^{18}$ rather, mine is a philosophical and jurisprudential inquiry. This inquiry is systematic, not historical: it aims to systematise the Pauline schema of law and love, not to reconstruct the personality of the historical Paul. Context is, of course, important. The issue is not whether to read Paul in context, but which context. The most immediate and relevant context here is not the historical context, but the contemporary philosophical,

16 Taylor, above $\mathrm{n} 2$.

17 Char Miller, 'Time of the Antichrist: Pauls' Subversion of Empire' (2009) 37 Political Theory 562, 565.

18 See, for example, Douglas Campbell, Framing Paul: An Epistolary Biography (Eerdmans, 2014); Robert Jewett, Dating Paul's Life (SCM Press, 1979); Rainer Riesner, Paul's Early Period: Chronology, Mission Strategy, Theology (Eerdmans, 1998). 
particularly jurisprudential, context. Between historical integrity and interpretive freedom, this paper indulges in the latter. The task of this inquiry is not to 'reconstitute what the original author said to the original audience'; rather, it is to 'retrieve something implied, implicit, a tendency that is possible, repressed, but astir in the text', thus allowing the text to blast from the past and speak to the present. ${ }^{19}$ In turning to Paul's letters, the goal is not to establish their true meaning exegetically or historically; rather, the goal is to invite readers to engage in an interpretive exercise that draws on those letters but presses towards an understanding of our contemporary predicament. ${ }^{20}$

My second methodological move is a movement from particular jurisprudence to general jurisprudence. Particular jurisprudence is the philosophical study of particular legal systems or traditions, such as the common law, Islamic law or Roman law. General jurisprudence, on the other hand, attempts 'to show, not what is law here or there, but what is law'21 as such, wherever and whenever it is found. On one level, Paul's jurisprudence is particular jurisprudence - it presents a critique of the Torah as a religious legal system. But, on a higher level, it may have something to say that is of interest to legal theory generally, that is, to general jurisprudence. 'Paul's comments may add something to our repertoire of ways of viewing systems of law. ${ }^{22}$ The methodology here is structural, not genealogical. My endeavour is not a genealogical study of how Paul's ideas were transmitted and transmuted from the past to the present. Instead, what I am attempting to do is to look at the structure of Paul's particular jurisprudence and to extrapolate from it to general jurisprudence.

Carl Schmitt famously said that 'all significant concepts of the modern theory of the state are secularized theological concepts'. ${ }^{23}$ In that sense, I have no objection to calling this paper a theological inquiry, but none of what I have to say about Paul presumes the existence or the non-existence of God. In fact, I should probably state it upfront that this paper has very little - almost nothing - to say about God per se. I approach Paul's letters with neither devotion nor repulsion. I have no particular religious or theological axe to grind. This paper is concerned with the Pauline structure of thought, especially its taxonomy of law and love. God may feature occasionally as a character in the story that I am telling, but the question of whether God exists is irrelevant to this inquiry. ${ }^{24}$

19 John Caputo, 'Postcards from Paul: Subtraction versus Grafting' in John Caputo and Linda Alcoff (eds), St Paul among the Philosophers (Indiana University Press, 2009) 1.

20 Paul Kahn, Out of Eden: Adam and Eve and the Problem of Evil (Princeton University Press, 2006) 12.

21 John Austin, Lectures on Jurisprudence or the Philosophy of Positive Law, Volume 1 (John Murray, 1885) 32.

22 Waldron, above n 3, 305.

23 Carl Schmitt, Political Theology: Four Chapters on the Concept of Sovereignty (George Schwab trans, MIT Press, 1985) 37.

24 A more religious reading of Paul, whether more pious or more theological, is always available. A more religious reading may even be richer. I am willing to 


\section{CRitique of $L A W$}

In order to appreciate Paul's critique of law, we have to begin with the concept of law in the Hebrew Bible. Law is part of Israel's juridical-theological covenant with God. The covenant with God is an 'alliance between God and his people [and the] observance of the law is what cements it'. ${ }^{25}$ Righteousness requires the maintenance of status within the covenantal community through obedience to the law of God, as revealed to Israel, the people of God. ${ }^{26}$ The law of God exists as positive law, as law that is posited by God to the Israelites: 'It presents itself canonically in written form, as a book or a code'. ${ }^{27}$ Admittedly, the positive law in the Hebrew Bible includes more than rules and commandments. In addition to rules and commandments, it consists of narratives, wisdom and prophecy. Indeed, I have argued elsewhere that law is irreducible to rules and commandments. ${ }^{28}$ But it is nonetheless true that the Bible, whether the Hebrew Bible or the Christian Bible, contains a lot of rules and commandments.

It is within this backdrop that we have to understand Paul's critique of the law. Although Paul's primary target is the law of Israel, his critique has much wider implications. He 'negates law as a force of political order', be it the imperial law of Rome or the theocratic law of Israel. ${ }^{29}$ Paul mounts a critique of the law on three fronts: logical, psychological and political.

According to Paul, 'where there is no law there is no transgression'. ${ }^{30}$ There is a fairly simple logical point here, which is that 'transgression logically presupposes law'. ${ }^{31}$ Hence, the logic of law is also the logic of transgression. 'Law is presented to its addressees as a set of ... nonnegotiable requirements, prescribing or proscribing the named action.' ${ }^{32}$ This feature is sometimes called the deontic character of law. Laws are not 'set

go as far as to concede that one cannot get a complete picture of Paul without adopting a religious lens. However, the purpose of this paper is not to present a complete picture of Paul. The richness of the religious reading has been widely canvassed in the past, indeed in the past two millennia. This paper wants to do something different. For Paul to speak to a contemporary audience, Paul has to be, for want of a better term, 'secularized'. Contra Alex Deagon, 'On the Symbiosis of Law and Truth in Christian Theology: Reconciling Universal and Particular through the Pauline Law of Love' (2015) 23 Griffith Law Review 589.

Tracy McNulty, 'The Event of the Letter: Two Approaches to the Law and Its Real' (2008) 29 Cardozo Law Review 2209.

26 EP Sanders, Paul and Palestinian Judaism (Fortress, 1977) 544.

27 Waldron, above n 3307.

28 Joshua Neoh, 'Text, Doctrine and Tradition in Law and Religion' (2013) 2 Oxford Journal Law and Religion 175; Ngaire Naffine and Joshua Neoh, 'Fictions and Myths in PGA v The Queen' (2013) 38 Australian Journal of Legal Philosophy 32; Joshua Neoh, 'The Rhetoric of Precedent and Fulfillment in the Sermon on the Mount and the Common Law' [2013] Law, Culture and the Humanities < $<\mathrm{x}$. doi.org/10.1177/1743872113494699>.

29 Jacob Taubes, The Political Theology of Paul (Dana Hollander trans, Stanford University Press, 2004) 121.

30 Romans 4:15 (Revised Standard Version, 1946).

31 Waldron, above n $3,311$.

32 Ibid, 315. 
out simply as rules of thumb or rather good ideas'. ${ }^{33}$ Law does not just commend; it commands. Law governs conduct by requiring that certain acts be done and by prohibiting other acts from being done. Law demands obedience. It 'tracks our observances and transgressions', and makes them 'available as occasions for punishment'. ${ }^{34}$

In addition to the relatively straightforward logical point, there is also a more complicated psychological critique, when Paul states that 'through the law comes knowledge of sin'.$^{35}$ Later, he adds that 'our sinful passions [are] aroused by the law'. ${ }^{36}$ One is here reminded of the forbidden fruit on the tree of knowledge in the Garden of Eden. As the saying goes, the forbidden fruit is the sweetest. Prohibition increases desire and stimulates transgression. Law 'makes all the more desirable the very thing it prohibits' ${ }^{37}$ 'By naming and individuating particular transgressions, the law actually puts them before our minds in a way that heightens their appeal to us. ${ }^{38}$ The knowledge of the law is causally related, in a psychological way, to its transgression.

The psychological origins of desire are manifold. Rene Girard, for example, locates the origin of desire in mimesis: we desire what others desire, that is, we want to have what others have.$^{39}$ However, we also want to have what we may not have: we also desire that which is forbidden. The forbidden fruit is desirable precisely because it is forbidden. Given the fecundity in the Garden of Eden, Adam and Eve would have been spoilt for choice in terms of fruits to eat. They would not have paid any attention to the forbidden fruit had the fruit not been forbidden. The prohibition transforms the fruit into an object of desire: 'the law chains us to an object precisely by forbidding it'. ${ }^{40}$

Law binds our conduct. In binding our conduct, it subordinates our will to its extraneous will. In subordinating our will to its will, it stimulates within its subjects a desire for freedom - it stimulates the desire for autonomy in response to the heteronomy of law. Freedom, in this sense, lies in the transgression of the law. Law is the site of resistance and transgression, and the concomitant assertion of freedom and free will.

The two logical and psychological arguments hint at a deeper political critique of law. In the Garden of Eden, when the prohibition against eating the forbidden fruit is issued, the nature of the relationship between God and humankind changes from an immediate relationship to a relationship that is mediated by law. Hence, when Adam and Eve eat the forbidden

$33 \quad$ Ibid, 316.

34 Ibid, 317, 325.

35 Romans 3:20.

36 Romans 7:5.

37 Craig Hill, 'Romans' in John Muddiman and John Barton (eds), The Oxford Bible Commentary (Oxford University Press, 2007) 1096.

38 Waldron, above n 3, 313.

39 See Rene Girard, Deceit, Desire, and the Novel (Johns Hopkins University Press, 1976).

40 Caputo, above n 19, 5. 
fruit, the transgression carries with it enormous political significance. Beneath the logic of transgression, there is a political psychology that is at work. The transgression signifies human disobedience and rebellion against the rule of God. As the Book of Genesis says, humans want to be like God. ${ }^{41}$ The ruled wants to be like the ruler. Underlying this transgression, there is a political struggle - that is, a struggle for power between the ruled and the ruler. Between God and humankind, who is to be dominant and who is to be subordinate? The forbidden fruit looks particularly tempting, not only because it is juicy and tasty, but because the eating of it represents the human desire to be free from the constraints of God's law: 'Only with the coming of the Law does man's sin take on the character of open rebellion'. ${ }^{42}$ Law exposes 'the deliberateness of human disobedience'. ${ }^{43}$ It becomes the 'primary source of human alienation' from God. ${ }^{44}$

In the prelapsarian state of divine-human harmony before the promulgation of the prohibition, there is an immediacy in the divine-human relationship. However, that immediacy is lost as soon as the prohibition is issued. That prohibition now stands between God and humanity. The prohibition is a prelude to the Fall: when the law is issued, its transgression is bound to follow as a matter of course. 'With the law, the [human] subject has definitively exited from unity, and from innocence. ${ }^{45}$ Law's prohibition awakens human pride. Instead of saving Adam and Eve from death, God's prohibition in the Garden lures them to their death. ${ }^{46}$ In the words of Paul, 'I was once alive apart from the law, but when the commandment came, sin revived and I died'. ${ }^{47}$ 'The law is no longer just an inadequate solution to the problem of sin; the law itself is the problem.' ${ }^{48}$ All this leads to the climax of the letter, when Paul proudly proclaims that 'Christ is the end of law'. ${ }^{49}$ Christ promises to restore the immediacy of the divine-human relationship.

\section{Counter Ideal of Love}

For Paul, Christ is love. The new Christian community promises to be a community sustained not by law, but by love. Paul has been called the apostle of love. ${ }^{50}$ His praise of love in his Letter to the Corinthians, for

$41 \quad$ Genesis 3:5 (Revised Standard Version, 1952).

42 WD Davies, 'Paul and the Law: Reflections on Pitfalls in Interpretation' (1978) 29 Hastings Law Journal 1459, 1480.

43 Hill, above n 37, 1094.

44 Ibid, 1086.

45 Badiou, above n 15, 82.

$46 \quad$ Hill, above $\mathrm{n} 37,1097$.

47 Romans 7:9.

48 Hill, above $\mathrm{n} 37,1096$.

49 Romans 10:4.

50 Or of hate: Nietzsche calls Paul the 'genius of hatred' with a 'relentless logic of hatred', who 'falsified the history of Israel, so as to make it appear as a prologue to his mission': Friedrich Nietzsche, 'The Antichrist: An Attempted Criticism 
example, is a staple lectionary reading for marriage liturgies. ${ }^{51}$ His zeal for love reinforces his proclamation of Christ as the end of law, for love is lawless, literally outside of law. In contrast to Moses who establishes the rule of law on Mount Sinai, Paul proclaims the power of love over law and asserts the inherent lawlessness of love. Borrowing Nietzsche's terminology, one of the significant 'transvaluation of values' which Paul effectuates is in his critique of the concept of law and the elevation of the value of love. ${ }^{52}$

According to Paul, 'He who loves his neighbor has fulfilled the law. The commandments, "You shall not commit adultery, You shall not kill, You shall not steal, You shall not covet," and any other commandment, are summed up in this sentence, "You shall love your neighbor as yourself." Love does no wrong to a neighbor; therefore love is the fulfilling of the law'. ${ }^{53}$ Love breaks the 'circuit or cycle of transgression and prohibition' by introducing a new way of being. ${ }^{54} \mathrm{~A}$ few verses later, Paul says that 'the 'kingdom of God is not food and drink' [that is, dietary laws], ${ }^{55}$ but 'walking in love'. ${ }^{56}$ Paul reduces 'the multiplicity of legal prescriptions' into a single, affirmative maxim; 'this single imperative envelops no prohibition - it is pure affirmation'. ${ }^{57}$ Paul contracts and recapitulates the entire corpus of Mosaic law 'in the figure of love'. ${ }^{58}$ As Paul says, 'love is genuine'. ${ }^{59}$ Love is that "which alone effectuates the unity of thought and action in the world'. ${ }^{60}$ For Paul, love is both a verb and a noun. As a verb, it denotes a particular way of acting in the world. But, more importantly, as a noun, it denotes a particular way of being in the world. Hence, it makes sense to say that God is love. Love as a noun precedes love as a verb: the state

of Christianity' in Oscar Levy (ed), The Complete Works of Friedrich Nietzsche, Volume 16 (Anthony Ludovici trans, Macmillan, 1964) 184ff.

511 Corinthians 13:1-8 (Revised Standard Version, 1946): 'If I speak in the tongues of men and of angels, but have not love, I am a noisy gong or a clanging cymbal. And if I have prophetic powers, and understand all mysteries and all knowledge, and if I have all faith, so as to remove mountains, but have not love, I am nothing. If I give away all I have, and if I deliver my body to be burned, but have not love, I gain nothing. Love is patient and kind; love is not jealous or boastful; it is not arrogant or rude. Love does not insist on its own way; it is not irritable or resentful; it does not rejoice at wrong, but rejoices in the right. Love bears all things, believes all things, hopes all things, endures all things. Love never ends'.

52 Taubes, above n 29, 26.

53 Romans 13:8-10.

54 Caputo, above 19, 5.

55 Romans 14:17.

56 Romans 14:15.

57 Badiou, above n 15, 89.

58 Agamben, above n 14, 108. We can call it the 'law of love', so long as we understand that this 'law of love' is a figure of speech, a rhetorical flourish and a paradox to drive home the point that, for Paul, love has replaced law. Whether that replacement or substitution is achieved, or is even achievable, is a separate question that will be addressed later in the paper.

59 Romans 12:9, according to Hill's translation: Hill, above n 37, 1104.

60 Badiou, above n 15, 91. 
of being in love leads to the performance of certain acts and endows those acts with a certain quality, such that we can call them acts of love.

We sometimes say that love is blind, by which we mean that love is radically contingent, spontaneous and even arbitrary - it appears as if from nowhere. One could express the same sentiment by saying that love is grace. Love as grace 'happens to everyone without an assignable reason'; 'grace is the opposite of law insofar as it is what comes without being due' ${ }^{61}$ Law operates within the logic of right and duty, 'granting to each part of the whole its due'. By contrast, grace is 'superabundant' with respect to 'the fixed distributions of the law' ${ }^{62}$ Grace is a gift, ${ }^{63}$ an unmerited favour, in contrast to a right or an entitlement. ${ }^{64}$ Law makes an act referable to a norm. By contrast, grace is divorced from any norm; it is a 'lawless eruption ... a pure act'. ${ }^{65}$ In Paul's terms, 'law came in', but 'grace abounded all the more'. ${ }^{66}$

Love is an act of grace that is rooted in faith. It is rooted in an abiding sense of fidelity to the subjective being of the other. Unlike the twelve apostles, Paul does not know Jesus in the flesh; he does not know the historical Jesus. He only knows Jesus as Christ. ${ }^{67}$ Love is 'tightly interwoven with faith' ${ }^{68}$ Like love and grace, faith too could be contrasted with law. The contrast that Paul draws between Abraham and Moses is precisely the contrast between faith and law - Abrahamic faith is contrasted with Mosaic law. And it is vitally important for Paul that Abrahamic faith precedes Mosaic law. In his words, 'the promise to Abraham and his descendants, that they should inherit the world, did not come through the law but through the righteousness of faith'. ${ }^{69}$ Faith is not a set of precepts, but a form of life. ${ }^{70}$ Speaking to the new Christian community in Rome, Paul says, 'We are discharged from the law, dead to that which held us captive, so that we serve not under the old written code but in the new life of the Spirit'. ${ }^{71}$ The word of faith cannot be reduced to a text - 'it cannot impose itself as a law'. ${ }^{2}$

What we have then is a triangulation of values: Love, Grace and Faith - love as an act of grace rooted in faith. Love becomes a 'form of discourse'73

61 Ibid, $76-77$.

62 Ibid, 78.

63 'His grace as a gift': Romans 3:24.

64 The Oxford English Dictionary (Oxford University Press, 1989) defines 'grace' as an 'unmerited favour' in contrast to a right.

65 Badiou, above n 15, 84.

66 Romans 5:20.

67 Agamben, above n 14, 126.

68 Ibid, 129.

69 Romans 4:13.

70 Agamben, above n 14, 122.

71 Romans 7:6.

72 Agamben, above n 14, 137.

73 Mark Poster, 'Review of Niklas Luhmann, Love as Passion: The Codification of Intimacy (Jeremy Gaines and Doris Jones trans, Harvard University Press, 1986)' (1988) 93 American Historical Review 1294, 1295. 
that stands apart from law. The discourse of love is antithetical to the discourse of law. Phrased in the strongest possible terms, one could say that Pauline love is antinomian. ${ }^{74}$

\section{RetURn to LAW}

While one could say that Pauline love is antinomian, it would be a mistake to leap from that statement to the conclusion that Paul's jurisprudence is an antinomian jurisprudence. Paul is not antinomian. He could not be. 'A messianic community that wants to present itself as an institution faces a paradoxical task. ${ }^{75}$ A messianic community looks towards eschaton, when the Messiah will return at the end of time to make things whole again. At eschaton, the world will be finally restored to perfection. In that perfect world, which is projected into the indefinite future, there may well be no need for law. However, Paul's messianic community is not there yet. There is an eschatological tension, or a temporal gap, between the 'now' and the 'not yet'. In the time that remains from now till 'the end of the world', Paul needs law as much as he may detest it. After driving a wedge between law and love, Paul still has to 'offer guidance for behavior'. ${ }^{76}$ 'In practice, what Paul expects of his converts is a fairly typical Jewish morality. ${ }^{77}$ Hence, Paul has to 'reinstitute Jewish laws with Christian warrants' by 'legislating rules of behaviour ad hoc'. ${ }^{78}$ Paul did not create 'a law-free religion': Christianity, like Judaism, has always had laws. ${ }^{79}$ After all his condemnation of the law, it turns out that there is a Christian list of acceptable behaviour, 'a Christian "law"' 80

At key points in his letters, Paul recoils from his condemnatory tone and adopts a conciliatory tone towards the law in a series of rhetorical questions:

'Do we then overthrow the law by this faith? By no means! On the contrary, we uphold the law'. ${ }^{81}$

'What then shall we say? That the law is sin? By no means! ... The law is holy, and the commandment is holy and just and good'. ${ }^{82}$

Like the prodigal son, Paul never ventures out of the law for too long. He soon returns to the law. Although Pauline love is antinomian, Pauline

74 The claim here is that the Pauline conception of love is antinomian, not that all conceptions of love are antinomian. The Johannine conception of love, for example, is strongly nomian in character. Jesus in John's Gospel presents a distinctly nomian kind of love when he says, 'If you love me, you will keep my commandments': John 14:15 (Revised Standard Version, 1946).

75 Agamben, above n 14, 1.

76 EP Sanders, Paul, the Law and the Jewish People (Fortress Press, 1983) 152.

77 Hill, above n 37, 1087.

78 Ibid.

79 Ibid.

80 Davies, above n 42, 1478.

81 Romans 3:31.

82 Romans 7:7-12. 
jurisprudence is not. Paul's thinking is still very much conditioned by the legal imagination. For example, Paul conceptualises Christianity as a covenant, albeit a new covenant. To speak in covenantal terms is already to speak in the language of law. The ancient theological covenant reminds us of the modern legal constitution. The Last Judgment, when justice would be done, is another classic example of legal language, couched in the form of judicial eschatology: ${ }^{83}$ 'the final judgment will legitimate believers by punishing unbelievers' - 'justice then becomes a dividing up' of one's due, which is the quintessential role of the law. ${ }^{84}$

Given the strongly negative statements that Paul has made about the law, there is a sense of 'embarrassment about giving full weight to the positive statements which Paul makes about the law'. ${ }^{85}$ He makes very little effort to reconcile the two sets of statements, 'prolaw' and 'antilaw'; 86 instead, he places them side-by-side. By cherry-picking, one could accuse Paul of antinomianism as much as one could accuse him of legalism. There is a deep bipolarity in Paul's attitude to the law, for he is both the harshest of legalist and the gentlest of lover. He wants to move from law to love, but he finds himself repeatedly pulled back into law. He is torn between the two. His jurisprudence of love is one that is marked by a recurrent tension between law and love.

While love is free, love is also fleeting. According to Paul, Christianity marks the end of law and the dawn of love, but it does not take long for the first church council to be formed and decrees to be issued. The promise of a lawless community ends up with codes of canon law. 'Already at the beginning of the fourth century, one finds a shift [from] the experience of the nearness of the word of faith to the assertive dogmatic content of the confession': the law returns with a vengeance. ${ }^{87}$

\section{Conclusion: JuRISPRUdence OF Love in CONTEMPORARY Discourse}

Paul's jurisprudence of love challenges the dominance of law. Scholars like Taylor, who calls the modern obsession with law 'rule fetishism' or 'nomolatry', ${ }^{8}$ are asking the same Pauline question: How could we 'relate ourselves to the law without becoming subservient to it?' 89 The modern political state carries with it this ancient theological dilemma. It inherits from Paul a particular cognitive dissonance, that of dreaming

\footnotetext{
83 Badiou, above n 15, 93.

84 Ibid, 94.

85 Sanders, above n 76, 159.

86 John Gager, Reinventing Paul (Oxford University Press, 2000) 9.

87 Agamben, above n 14, 135.

88 Taylor, above n 2, 347-366.

89 Jeffrey Bloechl, 'Between Love and Law: Paul and Philosophy' (Paper presented at the Simone Weil Lecture 2013, Australian Catholic University, Melbourne, 30 May 2013).
} 
in the language of love, but speaking in the language of law. ${ }^{90}$ We dream of 'freedom from law', just as we 'think it is impossible to have freedom without law'. ${ }^{91}$ We dream of relationships of love, even as we juridify our relationships. Notwithstanding the ascendancy of the rule of law today, the radical ideal of love as the ultimate negation of law remains a powerful eschatological vision in our theo-political imaginary.

Paul's jurisprudence of love invites us to reflect on the limits of law. It reminds us of our double and paradoxical sense of 'triumph and tragedy' in law: we measure the quality of our politics by the standard of law, but we measure the quality of our law by the standard of love. ${ }^{92}$ Law inevitably falls short because, beyond law, lies love, faith and grace. Unlike the legal mode of reasoning, 'we do not subject love to a means/ends [analysis]', for love is neither balanced nor proportional..$^{93}$ Love is an act of grace. 'Without proof or reason, love requires faith - a faith that the world can support love, ${ }^{94} \mathrm{a}$ faith in the goodness of oneself and others. Paul introduces 'a polemic that is as much in play today as it was in his own time'..$^{95}$

How one orients oneself towards the law affects how one imagines the alternative state of lawlessness. Lawlessness is, at bottom, the absence of law. ${ }^{96}$ Unlawfulness has to be distinguished from lawlessness: the unlawful is not the lawless. Crime, for example, is unlawful in that it contravenes the law. But crime, though unlawful, is part and parcel of the order and logic of law. In contrast, lawlessness is to step outside the order and logic of law entirely. Paul is simultaneously drawn to and repelled by lawlessness. Paul feels that law is inadequate; therefore, Paul dreams of love, grace and faith beyond law. However, there is the fear that, if one abandons law, one may end up, not in the dreamland of love, but in the nightmare of war, for love and war are both sites of lawlessness: hence, 'all's fair in love and war'. ${ }^{97}$ While love brings us back to Edenic paradise,

90 There is the perennial problem of the transposition of ideas across time and space. The problem should be acknowledged, but not exaggerated. In response to this problem, this paper appeals to love as a universal human experience and law as a universal mode of social relations. These concepts may have different conceptions across time and space, which result in them adopting different registers and idioms. Notwithstanding their polyvalence, they remain the same concepts if abstracted from their local conceptions. For the distinction between concepts and conceptions, see Ronald Dworkin, Law's Empire (Harvard University Press, 1986) 71-72.

91 Jerome Hall, 'Paul, the Lawyer, on Law' (1985) 3 Journal of Law and Religion 331, 379.

92 Paul Kahn, above n 1, xi-xii.

93 Paul Kahn, 'Political Theology Defended' (2012) 5 Jerusalem Review of Legal Studies 28, 33.

94 Ibid.

95 McNulty, above n 25, 2238.

96 Or 'the negation of law': Roberta Kevelson, 'The New Realism and Lawlessness in Kaleidoscope' in Roberta Kevelson (ed), Law and Semiotics, Volume 2 (Plenum Press, 1988) 189, 194.

97 This proverb, in its current form, is often attributed to Francis Smedley, Frank Fairleigh (W Scott, 1850). 
war brings us back to the Hobbesian state of nature. ${ }^{98}$ When one abandons law, the fear is that, instead of recovering Eden, one may end up in the Hobbesian state of nature: like Golding's boys, we may find ourselves killing each other and worshipping the Lord of the Flies. ${ }^{99}$ A move beyond law could either be an ascent into love or a descent into hate. Giving up law, one could either rise up to heaven or fall into hell. Lawlessness could either be utopian or dystopian.

Faced with this dilemma between law and love, we hedge our bets. While we live under law, we dream of love. While we juridicise our relationships, we lament the loss of love in those relationships. Like Paul, we think of ourselves as being committed to law, but we imagine ourselves as capable of love, grace and faith. Paul wants to have his cake and eat it too, and so do we. In the final part of this paper, I hope to illustrate this tension between law and love in the private domain of the family and the public domain of the polity. The illustration will be largely reliant on the works of others, and it will be broad-brush, for the purpose is not to produce a fine-grained image, but to highlight general trends of thought.

Let's begin with the family. On the one hand, there is a view of the home as an escape from the public world of law into the private realm of love. The 'glorification of private life and the family' represents the flip side of the perception of the public world as 'alien, impersonal, remote and abstract'; hence, 'deprivations experienced in the public world have to be compensated in the realm of privacy'. ${ }^{100}$ 'The family' thus becomes 'the last refuge of love', a haven in a heartless world. ${ }^{101}$ The uneasiness about importing law into the home and juridicising familial relationships stems from the concern that, if the family were to be pried open to the public world of law, the family would no longer be the site of love, grace and faith, but end up as broken 'shells of detached and competing individuals'. ${ }^{102}$ On the other hand, there is the competing concern that without law in the home - that is, if we allow the home to be lawless - the brute within us will emerge. Without law, the home may not be the refuge of love, but the site of domestic violence, that is, of brutality and monstrosity. Law is needed to control and subdue the inner brute in the public as well as the private sphere. The family is caught between the dream of love and the need for law: this is the reworking of the Pauline dilemma in the context of the family. Like the early Christian community, the family is torn between law and love as modes of interpersonal relationship, that is, as alternative ways through which its members could relate to one another. This mirroring of the Pauline dilemma in the family is perhaps

98 Thomas Hobbes, Leviathan (Andrew Crooke, 1651), in which he describes the state of nature as 'a condition of war of every one against every one' at ch xiv.

99 William Golding, Lord of the Flies (Faber and Faber, 1954).

100 Christopher Lasch, Haven in a Heartless World: The Family Besieged (Basic Books, 1977) 8.

101 Ibid, xiii.

102 Daniel Rodgers, 'Oedipus Deposed' (1978) 6 Reviews in American History 293, 294. 
unsurprising given that the early Christian community saw themselves as a family: not only did they profess to be brothers and sisters in the family of Christ, they lived as such, sharing their homes and possessions with one another. ${ }^{103}$

The image of the family is transposed to the religious community as well as the political community. Hegel sees the family as a microcosm of the polity, or inversely, the polity as an extension of the family: the familial and the political are two ends along the same continuum. ${ }^{104}$ The same tension between law and love in the private sphere of the family is replicated in the public sphere of the polity. On the one hand, the rule of law today constitutes our highest political ideal. No event, actor or claim escapes the rule of law. ${ }^{105}$ We need to fill the void of lawlessness with more law, because lawlessness is where bad things happen, both in public and in private. On the other hand, we are equally concerned about this trend towards the increasing juridification of our public and political space. We react, often strongly, against legalism in our public discourse. ${ }^{106}$ This reaction is sometimes manifested in terms of a critique of rights talk as an impoverishment of political discourse. ${ }^{107}$ The underlying intuition seems to be that there is, or should be, a deeper bond between us as a community of persons - as a people - than the one provided by the law. ${ }^{108}$ Rephrased in terms of the taxonomy of this paper, one could say that we lament the absence of love in our public life. With the Black Eyed Peas, we ask, 'Where is the Love?' In our moments of ecstasy, we have the eschatological vision of 'transform [ing] this world through love'. ${ }^{109}$

However, any talk of love in legal and political philosophy is immediately confronted with the challenge of demonstrating the viability of love as a political form of life. I am happy to bite the bullet and concede that love is not viable as a political form of life. It is sometimes said that 'the position of Paul doesn't imply any positive political form'. ${ }^{110} \mathrm{I}$ agree, but in a qualified sense. The place of love is not in our political practice, but

103 'All who believed were together and had all things in common ... The company of those who believed were of one heart and soul, and no one said that any of the things which he possessed was his own, but they had everything in common': Acts of the Apostles 2:44, 4:32 (Revised Standard Version, 1946).

104 Joan Landes, 'Hegel's Conception of the Family' in Jean Elshtain (ed), The Family in Political Thought (University of Massachusetts Press, 1982) 125.

105 Kahn, above n 1, xvi.

106 Judith Shklar, Legalism (Harvard University Press, 1986); Zenon Bańkowski, 'Law, Love and Legality' (2001) 14 International Journal for the Semiotics of Law 199; Jay Michaelson, 'Hating the Law for Christian Reasons: The Religious Roots of American Anti-Lawyerism' in Suzanne Last Stone and Ari Mermelstein (eds), Jews and the Legal Profession (forthcoming).

107 Mary Ann Glendon, Rights Talk: The Impoverishment of Political Discourse (The Free Press, 1991).

108 Vivian Liska, 'A Lawless Legacy: Hannah Arendt and Giorgio Agamben' in Marco Goldoni and Christopher McCorkindale (eds), Hannah Arendt and the Law (Hart Publishing, 2012) 89, 96.

109 Werner Jeanrond, A Theology of Love (T\&T Clark, 2010) 228.

110 Taubes, above n 29, 121. 
in our political imagination. We routinely imagine lives that we do not currently live, or lives that we have not seen. Heaven and hell are the first examples that come to mind. Other examples include the Hobbesian state of nature and the Edenic paradise on earth. But to say that love in politics is imaginary is not to say that it is illusory. It is an imaginative ideal by which we measure our actual life in the flesh.

Arendt, notably, regards love as inherently unpolitical and hence, unworldly. According to Arendt, love is 'killed, or rather extinguished, the moment it is displayed in [the] public [sphere]'. ${ }^{111}$ For Arendt, the 'world' is a term of art which signifies a public space which gathers people together 'to relate and to separate them'. ${ }^{112}$ To use an Arendtian simile, the world is like a table which simultaneously separates and relates those who sit around the table. Her project, therefore, is a 'politics of world-building'. ${ }^{113}$ Law is an integral part of that project insofar as law supplies us with a set of rules, which mediate our interpersonal relationships. Our relationships are mediated through a framework of rules, which simultaneously relate and separate us from one another. In contrast, Christianity, especially the Christian love of the Pauline sort, 'represents a dangerous otherworldliness for the political mind of Arendt'. ${ }^{114}$ 'Its intimacy or closeness necessarily results in the destruction of the public space among persons.' ${ }^{115}$ This sort of love is only suited for a worldless people, or to be more accurate, an otherworldly people.

Arendt may be right in her assessment that love has no political form, but my argument here is that it has an idealised form in our legal and political imagination. In a recently published book on political love, Martha Nussbaum agrees that 'all love has aspects of the ideal', but then argues that 'ideals are real': 'real people aspire' - 'they imagine possibilities better than the world they know, and they try to actualize them'. ${ }^{116}$ We can dream about love in politics, even if we do not live the dream. Paul's jurisprudence of love reflects precisely that division between vision and reality - between the eschatological desire to escape from law to love, and the earthly gravitational pull back to law. He begins with a radical critique of law and posits what Arendt would think of as the otherworldly ideal of love. However, a community, even one as otherworldly as the early Christian community, needs laws to govern behaviour and mediate interpersonal conduct. Despite their best efforts to escape this world, they were still living in this world. Living in this world means living under governments, both secular and ecclesiastical, and under laws, both civil and canon - hence, the tension between law and love. If the other-worldly

111 Hannah Arendt, The Human Condition (University of Chicago Press, 1958) 51.

112 Ibid, 52-53.

113 Shin Chiba, 'Hannah Arendt on Love and the Political: Love, Friendship and Citizenship' (1995) 57 Review of Politics 505, 523.

114 Ibid, 524.

115 Ibid, 517.

116 Martha Nussbaum, Political Emotions: Why Love Matters for Justice (Harvard University Press, 2013) 384. 
Christian community cannot live on love alone, the thoroughly thisworldly political community is unlikely to fare any better. Love is not all we need. ${ }^{117}$ But neither can we live without love.

Paul's jurisprudence of love is an attempt to 'grapple with the perennial and often insoluble dilemma' ${ }^{118}$ between the two extremes of legalism and antinomianism. Paul has a vision, in which love would make law superfluous. However, that vision clashes with the stark reality of our fallen state. In our fallen state, lawlessness may not be a return to the prelapsarian Edenic paradise of love, but a descent into the Hobbesian state of nature, where there is nothing but war, and life is nasty, brutish and short. Law and love exist in tension in the liminal space between our fear of descending into the Hobbesian state of nature and our dream of returning to the Edenic paradise on earth. Law and love are situated within a soteriological narrative: law may be necessary to save us from the Hobbesian state of nature, but it is love that will bring us back to Edenic paradise. 'In imperfect states and for imperfect human beings', Paul recognises the need for law. ${ }^{119}$ Nonetheless, in his grand vision, he imagines a state of perfection and redemption, in which he dreams of love, grace and faith.

117 Contra The Beatles, All You Need is Love (1967).

118 Heikki Raisanen, 'Paul's Conversion and the Development of His View of the Law' (1987) 33 New Testament Studies 404, 416.

119 Hall, above n 91, 378. 